\title{
JANGWA WEDDING SONGS AMONG THE MANYIKA PEOPLE OF ZIMBABWE: CULTURAL MEANINGS AND FUNCTIONS CONVEYED THROUGH SONG LYRICS
}

\author{
Viola Mugandani
}

University of Pretoria

viola.mugandani@up.ac.za

\section{Dorette Vermeulen}

University of Pretoria

Dorette.Vermeulen@up.ac.za

\section{ABSTRACT}

Jangwa music is indigenous to the Manyika people of Zimbabwe. African societies carefully craft song texts for different contexts to serve a functional and educational purpose, and an investigation was undertaken to explore the ways in which this is embodied through jangwa wedding music. The aim of this article is to discuss the cultural meanings and functions conveyed through song lyrics amongst the Manyika people of Zimbabwe. Since the young generation no longer values traditional music being performed at weddings, 150 elderly Manyika people acted as key informants, performing jangwa songs of which they had extensive knowledge and experience. Data collection strategies included participant observation, in-depth interviews and focus-group discussions. Most jangwa wedding songs have a positive outlook and encouragement for the newly-weds, while other songs are more critical and warn of the possible pitfalls in marriage. Findings revealed that the majority of jangwa wedding songs focus on the role of brides and married women as a whole, signifying the pivotal role they play within the Manyika society. Active participation in indigenous African musical arts is diminishing, therefore a concerted effort is needed to ensure that jangwa wedding music is revived and documented for future generations.

Keywords: Jangwa; wedding songs; Manyika; Zimbabwe

\section{UNISA}

Southern African Journal for Folklore Studies 


\section{INTRODUCTION}

Jangwa music, the focus of this article, is an important traditional music style of the Manyika people of Zimbabwe. The Manyika are a segment of the Shona people, occupying a part of Manicaland Province in the eastern part of Zimbabwe (Law 2005). The Manyika communities are ruled by chiefs who inherit their positions, and accordingly, the regions are called after the family names of the specific chieftainships. These include Mutasa, Makoni, Marange and Zimunya. History reveals that some of the Manyika people migrated from one district to the other in search of fertile agricultural lands. Owing to the British colonialist racial segregation land ownership policy, the Manyika people were forced to migrate from the fertile Makoni and Mutasa areas to the less productive infertile low veldt of Marange and Zimunya with less rainfall (Utete 1979, 12-13). As a result of this migration the culture of the people from these regions - part of which is conveyed through jangwa music - is similar.

Jangwa music developed as a choral tradition during the post-colonial era, and songs performed at wedding ceremonies became one of its main functions. During these occasions, life skills and knowledge about married life were shared with the young couple through jangwa songs. Like other African music, jangwa music integrates traits such as lead and response (Haecker 2012, 58); cyclic or repetitive form (Nzewi and Nzewi 2007, 32); and interlocking rhythms and Western harmony (Turino 2000, 55). Similar to church makwaya music, jangwa music is based on Western harmony and was originally created by elderly community members who were well versed with the expectations of married couples in the Manyika culture. Songs were rehearsed in the evenings by the younger generation in preparation for wedding ceremonies which were to be held during the day. The term jangwa is linked to a small animal of the same name and which looks like a squirrel. These little scavengers rummaged for prey in the evenings, the same time the young performers rehearsed the songs. Movements made during the singing of jangwa songs imitate the movements made by the little animal.

There is an eminent danger of enculturation taking place at the expense of traditional African wedding rituals. Presently the young generation is in favour of Western recorded music which, in most cases, does not promote African cultural values; hence traditional music is at the brink of extinction. As indicated by Mupotsa $(2014,65)$, the norm for contemporary African weddings is that two ceremonies take place; an "amalgamation of African cultural practices and Western white wedding rituals", which could lead to a loss of indigenous wedding music.

Bebey $(1999,115)$ suggests that the purpose of African music is not necessarily to produce agreeable sounds for the sake of the sound, but to translate everyday communal experiences into living sounds. Members of a community engage in 
group singing as part of organised activities with specific functions (Adedeji 2006, 4) where knowledge is shared through songs. A review of the literature suggests that meanings and functions of song lyrics in African music are of paramount importance as they reveal the indigenous culture of a particular society. Such cultural patterns, as well as the incorporation of foreign patterns of life among the contemporary Manyika people of Zimbabwe, are unveiled in the research findings shared in this article.

\section{METHODOLOGY}

In order to gain an in-depth understanding of jangwa music and its lyrics, a focused ethnographic study within a qualitative paradigm was employed (Knoblauch and Schnettler, 2012). Since no published transcribed jangwa music could be found, elderly Manyika people are currently the only key informants of this unique traditional music. Therefore, a sample of elderly people (97 women and 53 men) from the four chieftainship areas in Manicaland was purposively selected. This allowed for observations of the participants' lived experiences during field visits, capturing auditory and kinaesthetic details of song performances. As the primary data collector was born and living in Manicaland for the greater part of her life, this increased access to the geographical terrain and provided familiarity with the research area (Knoblauch 2005, 5).

All participants - apart from nine due to their old age - took part in choral performances, after which they joined focus-group interviews. The nine seniors were individually interviewed according to a semi-structured interview schedule with open-ended questions.

Through singing, interacting, and dialogue with the performers as participant observer during the four jangwa wedding song performances, the primary data collector obtained an insider or "emic" perspective (Nieuwenhuis 2016, 91). This elicited an untold understanding of the meanings and functions of jangwa song lyrics. During focus-group interviews, participants spontaneously interacted amongst each other, correcting misinterpretations or adding more information as the discussions flowed (Babbie and Mouton 2008, 292; Nieuwenhuis 2016, 95). In addition, information gleaned through participant observation could be verified during focus-group discussions by asking specific questions regarding movements and interpretation of the songs.

Interviews and song lyrics were transcribed, translated into English, scrutinised and interrogated by both researchers to interpret the underlying meanings. Similarly, video-recordings of the performances were cross-examined and reflected upon as a way of substantiating the information (Knoblauch 2005, 11; Leedy and Ormrod 2005, 377). 


\section{FINDINGS}

Jangwa wedding song lyrics, as suggested by the participants, are related to a specific way of life, bringing out much of the beauty of the music among the Manyika people. The findings distilled from data obtained during the individual and focus-group interviews, suggest that most of the jangwa songs, generated by a multiplicity of roles, are associated with weddings and marriages. Of the 33 jangwa wedding songs performed during data collection, 21 were songs particularly sung for the bride while only eight were for the bridegroom. Four of the songs could be sung to encourage unmarried young men and women to get married through Western white weddings.

In the following sections, three types of songs will be described namely songs for the bride; songs for the bridegroom; and songs for unmarried young men and women.

\section{SONGS FOR THE BRIDE}

All focus groups and individual interviewees agreed with the notion that songs for the bride focus on the significant changes in the roles of a woman once she gets married. One of the interviewees said (free translation):

Wedding songs taught the newlyweds of the changing responsibilities in their lives. Songs for the bride were different from songs for the bridegroom because their responsibilities were different.

Asked to elaborate on the reasons why so many songs focus on this theme, it was unanimously agreed that the Manyika cultural roles or functions, which are embedded in the jangwa songs, were created to unveil the multiple roles of the bride. According to the participants, the bride is seen as a muroora (daughter/sister-inlaw), a mudzimai (wife), a mai (mother), a mainini (aunt from the mother's side or second wife to the father), and a shamwari (friend). As a muroora (daughter-in-law) the newlywed wife is treated by the community as a pillar of the home. However, the mirror image of pillar-of-the-home symbol conceals the invisible and absolute power which the traditional Manyika wife wields within her domestic domain. In this respect, the Manyika have the saying, musha mukadzi (home is home because of the woman). Categories which emerged from songs for the bride are included in the following sections, and examples of songs depicting, each role together with the meaning of the lyrics, are given to support the findings.

\section{- Domestic chores}

Some of the songs sung for the muroora highlight the domestic chores she is expected to do in the marriage household. For instance, in one of the song performances, Ngaitongwe nyaya (Let the case be resolved), one of the central objectives of a 
marriage in the Manyika culture - and indeed in all traditional African marriages - is highlighted. The man needs to get married and bring his wife home to help his parents and other family members in doing all domestic chores before she and her husband build their own home. When the newlyweds have their own home, the bride is still responsible for the domestic chores, but this is within her own territory. Thus, in the jangwa song, the singers plead on behalf of the groom's family for a strong bride or daughter-in-law. This daughter-in-law should be capable of efficiently performing the different chores in the husband's homestead. The following excerpt of this song's text is given below, projecting the meaning of the lyrics:

$\begin{array}{cl}\text { Lead (Soprano) } & \begin{array}{l}\text { Ngaitongwe } \\ \text { (Let it be resolved) }\end{array} \\ \text { Response (All) } & \begin{array}{l}\text { Nyaya, ngaitongwe nyaya yacho } \\ \text { (Let the real issue be resolved) }\end{array} \\ & \text { Tinode muroora wakagwinya (x3) } \\ \text { Lead (Bass) } & \text { (We want a fit daughter-in-law) (x3) } \\ & \text { Anoenda kutsime } \\ & \text { (Who goes to the well) } \\ & \text { Ngaitongwe } \\ \text { (Let it be resolved) } & \text { Nyaya, ngaitongwe nyaya yacho } \\ \text { Response (All) } & \text { (Let the real issue be resolved) } \\ & \text { Tinode muroora wakagwinya (x3) } \\ \text { Lead (Bass) } & \text { Anochant a fit daughter-in-law) (x3) } \\ & \text { (Who constructs contour ridges) }\end{array}$

It is evident from the lyrics of the different lead and responses that the muroora is not only expected to do domestic chores such as fetching water - probably from the river - and cleaning the courtyard. She is also required to do some form of subsistence farming near the homestead, ensuring the field is not eroded by the rains. This is exemplified by the lyrics of the last phrase as transcribed in the song text above ([The daughter-in-law] who constructs contour ridges).

In another song, Muroora wauya, shamwari yekuhuni (the daughter-in-law has come, a friend to go out fetching firewood with), this role of the new bride, doing domestic chores and assisting others in the fetching of firewood for the family, is shared.

\section{- Friend and companion}

The role of the bride as a symbol of friendship and an anchor of comfort and support for the younger female members of her husband's family was highlighted by one of the participants, who stated the following (free translation): 
It is not that the bride would do the work on her own, but rather that the people of that homestead - such as the husband's sisters - would say that they found someone to accompany them in the home chores, a friend to help them.

The muroora's communal companionship role - aimed at protecting the husband's younger sisters - was introduced by one of the participants during a focus-group discussion. In the song, Muroora wauya, (The daughter-in-law has come), the additional role of companionship is highlighted in the lyrics:

Lead: $\quad$ Muroora wauya

(The daughter-in-law has come)

Response: Hee wauya

(Yes she has come)

All: $\quad$ Shamwari yekuhuni wauya

(A friend with whom to fetch firewood has come)

Several interviewees indicated that the muroora would be accompanied to fetch firewood by her sisters-in-law because they knew where they would find firewood. The participants further explained that it does not mean that the muroora is a companion only during fetching firewood, but in other domestic chores as well. From further analysis, the song particularly emphasises the notion that the Manyika institution of marriage is not a lonely rite of passage which subjects brides to endless cycles of domestic chores. She is not treated as an alienated and lonely member of her husband's homestead, who carries the burden of the domestic chores alone, and is exploited as a "housekeeper" by her in-laws. The muroora is expected to be warmly welcomed and treated as a friend who accompanies members of the family, especially the husband's young sisters, when carrying out their various duties. Most importantly, the muroora is taken as a confidante by the sister-in-laws. One 72-year old interviewee said (free translation):

The sisters-in-law would talk about their boyfriends to her, and in turn she taught them how to conduct themselves in their relationships, and this usually happened when they were out looking to fetch firewood.

The deeper or hidden meaning is that the muroora is a confidante who helps to mould the younger sister-in-laws into acceptable girlfriends and wives to be. As a confidante, her husband's sisters share their secrets with her. This is a virtue which, according to the interviewees, is still prevalent among the Manyika people today.

When the two songs discussed above - Ngaitongwe nyaya and Muroora wayya - were submitted to further textual scrutiny, they appeared to be structured around two conflicting narrative voices; one a positive and the other a more negative view. While the song Ngaitongwe nyaya perceives the muroora as a "housekeeper", the song Muroora wauya treats her as an important and respected member of her husband's family. The text Ngaitongwe nyaya (Let the issue be resolved) in the first 
song already suggest that there is a problem: that of a lazy bride or daughter-inlaw in this case. The bride's relatives are warned that their daughter has to be hard working. On the other hand, the word shamwari (a friend) in the second song affirms that the bride is welcome in the family as a friend.

\section{- Organiser of the home}

Further scrutiny of the song Ngaitongwe nyaya (Let the case be resolved) suggests that the prescribed roles of Manyika married women do not only posit domestic work but that out of the work come some benefits. This is where the notion of musha mukadzi (home is home because of the woman) as earlier indicated, comes in. The compliant muroora gets the benefit of having the home as hers. The phrase musha mukadzi seems to bring out the idea that the Manyika society, to a greater extent, respects married women. The perception shared through musha mukadzi means that when a woman is responsible and organised it helps to bring order, stability and prosperity in the home. For these reasons the Manyika talk of a home as kwamai Tendai (Tendai's mother's home) as opposed to kwababa aTendai (Tendai's father's home). As a result the words musha mukadzi are even inscribed in the women's basketry displayed in some kitchens.

\section{- Sexual role of the bride}

According to the interviewees, there are concealed meanings in some of the songs. From a contemporary African feminist perspective, the song Ngaitongwe nyaya (Let the case be resolved) highlights the perspective that all the expected benefits that should accrue to the muroora from the Manyika marriage, appear to culminate in an endless cycle of domestic chores. The focus-group interviewees, however, insisted that there is a hidden beauty in this song, which an 81-year old woman explained as follows (free translation):

Some of the songs have hidden meanings; they teach the work of a woman as a wife in the home. Wives must be strong every time, even in the evening when they go to sleep they should still have the energy to engage in sexual intercourse with their husbands.

Two of the most important roles of brides in the Manyika culture are to procreate and to provide all the sexual needs of the husband. These roles, subtly suggested in the lyrics of the songs, were confirmed by the Manyika participants.

\section{- Role of mother}

The woman's strength, according to an 81-year old matriarch, would mainly be in her ability to give birth and thereby increase numbers in the family population; a view endorsed by all the participants. This leads to songs about the bride as a mother, of 
which Iyo hoo ndege (There is an aeroplane) is an example. One of the participants, who explained the meaning of this song, said (free translation):

She [the bride] is respected because the husband's family will be saying that we are getting a mother, who will make the family grow, her respectable position in the family warrants her to be transported into the new home in an aeroplane.

The song lyrics are as follows:

$\begin{array}{ll}\text { Lead: } & \begin{array}{l}\text { Iyo hoo ndege } \\ \text { (There is an aeroplane) }\end{array} \\ \text { Response: } & \begin{array}{l}\text { Yatumwa ndiMawoyo } \\ \text { (Sent by Mawoyo) }\end{array} \\ \text { All: } & \begin{array}{l}\text { Iyo hoo ndege } \\ \text { (There is an aeroplane) }\end{array} \\ \text { Response: } & \begin{array}{l}\text { Enda wotora mai } \\ \text { (Go and fetch mother) }\end{array}\end{array}$

The mammoth task of being mother within the Manyika institution of marriage - a crossroad within the rite of passage - is so monumental that the newlywed has to be transported in the most esteemed form of transport - an aeroplane - to be flown from her home to her husband's family homestead. While flying is only imaginary, the song symbolises the bride's prestigious role of being a mother. Among the different forms of transport which were introduced by the colonialists, such as cars or buses, the groom's father chooses the best and most expensive form of transport namely the aeroplane to indicate the value placed on her role as mother in the family.

\section{- The bride as additional wife}

Mainini is a supplementary term the Manyika use for the bride, signifying another role which she could take. This term refers to an additional wife in a polygamous situation, and is embedded in the song Mainini, ane nharo tinonera (Aunt, we will beat the unruly one). Since there is no corresponding term in English signifying the specific role of additional wife, the word "aunt" is used in the translation. The lyrics of the song are as follows:

$\begin{array}{ll}\text { Lead: } & \begin{array}{l}\text { Mainini } \\ \text { (Aunt) }\end{array} \\ \text { Response: } & \begin{array}{l}\text { Ane nharo tinonera } \\ \text { (We beat the unruly one) }\end{array} \\ \text { Lead: } & \begin{array}{l}\text { Chokwadi } \\ \text { (Surely) }\end{array} \\ \text { Response: } & \text { Ane nharo tinonera neshamu } \\ & \text { (We beat the unruly one with }\end{array}$

(We beat the unruly one with a cane) 
According to the interviewees, additional wives are generally undesirable among the females of the Manyika families. They are considered quarrelsome and often seeking favours from the husbands at the expense of the first wives, thus causing instability in the household. In the above song, the bride is taken as a second wife and she is warned not to be unruly or else she will be reprimanded. The deeper insight, as revealed during the interviews, is that she is advised to respect her mother-in-law because, according to the Manyika tradition, the bride should treat the mother-in-law with esteem and take her as her biological mother.

The song Joyce mwanawe (Joyce, our child) indicates the views from the bride's side of the family regarding their daughter being beaten, in response to the song discussed above. The lyrics of this song are:

$\begin{array}{ll}\text { Lead: } & \begin{array}{l}\text { Joyce } \\ \text { (Joyce) } \\ \text { Response, Joyce mwanawe } \\ \text { (Joyce, Joyce our child) }\end{array} \\ \text { Lead: } & \begin{array}{l}\text { Kurohwa unanyarara } \\ \text { (When beaten be quiet) }\end{array} \\ \text { Response: } & \begin{array}{l}\text { Kurohwa unanyarara, kurohwa unanyarara mwanawe } \\ \text { (When beaten be quiet, when beaten be quiet, our child) }\end{array}\end{array}$

The narrative voice of this song affirms rather faintly the need for the bride to fulfil the expectations of her in-laws. This song indicates that the bride's family approves of the groom's actions, advising her that she should not speak out when beaten; she should be submissive to her husband and the in-laws. As revealed by the participants, this is a virtue that is common among the Manyika, including the Shona people as a whole.

Comparing songs for the bride from the groom's side of the family with those from the bride's side of the family, it is evident that the groom's family sings songs of joy, celebrating that they are gaining a daughter-in-law, a sister-in-law, a mother, a wife, an aunt, a companion and friend, a helper with domestic chores, as well as somebody to extend the family and produce children. On the other hand, songs sung by the bride's family for their daughter have a different tone; most of the songs expressing sadness. In this respect, a participant noted the following (free translation):

Most of them [songs sung by the bride's family] are for expressing the pain of losing their daughter to the family she is marrying into.

One of the main functions of jangwa song lyrics from both sides of the family, then, is to prepare the bride psychologically for the multifarious roles ahead of her. 


\section{SONGS FOR THE BRIDEGROOM}

During jangwa music performances when data were collected, it became evident that very few songs were sung specifically for the bridegroom. The reason for this may be that the traditional husband in the Manyika community experiences less dramatic changes in his life, still living in the same homestead and maintaining similar responsibilities. Regarding the purpose of jangwa songs for the bridegroom, one of the participants commented (free translation):

The bridegroom is also taught the changing responsibilities as he gets to be the father, head of the family.

The following song, Hema, hema, is full of irony, teaching the bridegroom in a subtle way to be a man of virtue with good moral behaviour; someone who works for his family. The text of the song is as follows:

$\begin{array}{lll}\text { Lead: } & \text { Hema, hema, hema, hema } & \text { (Hey mother, hey mother, x2) } \\ \text { Response: } & \text { Hema, hema } & \text { (Hey mother, Hey mother) } \\ \text { Lead: } & \text { Ndakanzwa kuti } & \text { (I heard that) } \\ \text { Response: } & \text { Hema, hema } & \text { (Hey mother hey mother) } \\ \text { Lead: } & \text { Mwana wenyu imbavha } & \text { (Your child is a thief) } \\ \text { Response: } & \text { Hema, hema } & \text { (Hey mother, hey mother) } \\ \text { Lead: } & \text { Handina k'mbozvimainda } & \text { (I never minded) } \\ \text { Response: } & \text { Hema, hema } & \text { (Hey mother, hey mother) } \\ \text { Lead: } & \text { Ngekuti ndaimuda } & \text { (Because I loved him) } \\ \text { Response: } & \text { Hema, hema } & \text { (Hey mother, hey mother) }\end{array}$

Scrutinising the text, the irony is clear, indicating a clash between love and immorality in the traditional African marriage. The bride's family sings on her behalf, expressing to the mother-in-law that, no matter what immoral behaviour her son indulges in, the new bride does not mind because she loves him dearly. The literal meaning of the song suggests that love is blind. When people are in love, they do not seem to care about the weaknesses of their partners.

The groom is taught or reminded through song to be a responsible, loving husband, and, similar to the song Ngaitongwe nyaya for the bride, the bridegroom is reminded to perform well sexually after a long day of rigorous work. Married men were generally reproached, advised and remoulded through jangwa wedding songs, while the bride's family often sang songs to tease the bridegroom, adding sentimental messages. An example of such a teasing song is Ronga zirende (He looks like a wild cat). The prefix " $z i$ " implies "big and ugly", meaning the bridegroom is likened to a big, ugly wild cat. As the bride's sisters sing a song such as Ronga zirende, they point to the groom, making faces at him, and really enjoying teasing the groom. This adds to the whole performance being entertaining and humorous to all wedding guests. The lyrics of the song are as follows: 
Lead: $\quad$ Patrick ronga zirende pacheya

(Patrick looks like a wild cat on the chair)

Response: Ronga zirende

(Looks like a wild cat)

\section{SONGS FOR UNMARRIED YOUNG MEN AND WOMEN}

Besides rehearsals of songs for wedding days, according to the participants, in former times young men and women would sing wedding songs for recreation in the evening moonlight, after a long day's work. If a couple intended to marry, the young woman would be taken to the new husband's home by her aunts - her father's sisters - after lobola has been paid. Some couples got married after the young woman would be pregnant. Therefore, to protect the young women, white weddings in the Western tradition were introduced to the Manyika by missionaries, which added a legal component to the wedding ceremony. These weddings which legitimised the marriage were welcomed, becoming an important element of culture among the Manyika people. According to the participants, specific songs were sung to encourage young men and women to get married according to Western tradition, signing legal documents and obtaining certificates to make the marriage legitimate. An example of a song appropriate for such an occasion is Dhindai mapepa (Stamp the marriage certificates). The lyrics of the song are as follows:

\begin{tabular}{|c|c|}
\hline Soprano lead: & $\begin{array}{l}\text { VaMawoyo wee } \\
\text { (Mr Mawoyo) }\end{array}$ \\
\hline Response: & $\begin{array}{l}\text { Ewo, ewo, ewo, ewo } \\
\text { (Yes, yes, yes, yes) }\end{array}$ \\
\hline Soprano Lead: & $\begin{array}{l}\text { VaMawoyo wee } \\
\text { (Mr Mawoyo) }\end{array}$ \\
\hline Response: & $\begin{array}{l}\text { Dhindai mapepa awe, } \\
\text { (Stamp the certificates) }\end{array}$ \\
\hline All & $\begin{array}{l}\text { Kuti dhindewo ewo, muise kuna ishe VaMaponde } \\
\text { (As in real stamping, send them to chief Maponde) } \\
\text { Kuti dhindewo ewo, muise kuna ishe. } \\
\text { (As in real stamping, send them to the chief. }\end{array}$ \\
\hline Bass lead: & $\begin{array}{l}\text { Dhindai mapepa, dhindai mapepa awe } \\
\text { (Stamp the certificates, stamp the certificates) }\end{array}$ \\
\hline
\end{tabular}

Songs such as Dhindai mapepa were regularly sung during wedding ceremonies as well as during rehearsals before the wedding, thereby encouraging young couples to get married legitimately through Western white weddings. 


\section{DISCUSSION}

Tracey and Uzoigwe's $(2003,75)$ argument - namely that African music tends to bring out those things that African people value in life - was the lens through which the lyrics were analysed. In this respect, it became evident that jangwa wedding songs are deeply rooted in cultural traditions and that basic truths about married life are shared through the songs. These lyrics convey values, virtues, and life skills, and are therefore inextricably bound to the indigenous fabric and context-specific utilitarian purposes of the music. This corresponds to findings of other authors regarding indigenous African music (Adedeji 2006; Chinouriri 2012; Mans 2006; Nzewi 2003), indicating the "importance of...collective responsibility, communal ties, etiquette [and] discipline" (Wanyama 2005, 6-2).

A multitude of indigenous knowledge systems abound in Africa (Mugovhani 2012, 4). Music is an important vehicle to transmit norms for suitable behaviour during the transitional stage of life of being unmarried to becoming ready for marriage. Topics and issues which are regarded as inappropriate to be discussed under normal circumstances (Mindoti 2006, 158), such as sexual and utilitarian roles of brides and grooms in marriage, can be conveyed with ease through song lyrics, as exemplified through jangwa wedding music. Some of the most fundamental normative utilitarian roles of African wives are traditionally taught by communal women in female initiation schools (Blacking 1976, 38; Dontsa 2007, 394). Similarly, the lyrics of the traditional jangwa songs have additional or hidden meanings and should not be taken at surface level only. The multi-layered meanings of the lyrics in African songs concur with the findings of studies conducted by researchers such as Adedeji (2006), Mans (2006), Nzewi (2003), and Wanyama (2006).

Song lyrics often add social commentary and criticism where women indirectly complain of the extensive chores they have to carry out in the absence of their husbands. Agawu $(2003,5)$ refers to this trait as "providing musical commentary that encodes criticism of society", but that these are "necessary to the achievement of a balanced life". Similarly, Nzewi (2003, 16-17) observes the use of music as an agent for social criticism. While the whole process of music performance plays a role in the shaping of individuals, song lyrics play a more significant role. Indigenous social criticism songs are common among the Manyika. Such songs include Mwajaira kudya zvekukwata (You are so used to feeding from homestead to homestead without providing food for your family), which criticises lazy people who do not work to provide food for their families, but who abuse the kindness of their neighbours. While some jangwa wedding songs have a positive outlook and encouragement for the newly-wed couple, other songs are more critical and warn the bride and groom as well as the wedding guests of social conduct and possible pitfalls in marriage. This dichotomy or union of opposites corresponds with Dontsa's findings regarding intonjane music $(2007,393)$. Similarly, Jangwa wedding song lyrics highlight the 
multifarious roles of the bride as alluded to by Gilbert's $(2003,1)$ notions of double or multiple belonging leading to different selves.

Jangwa wedding songs for the bridegroom - sung by the bride's family - is often done in a spirit of playful teasing, sending sentimental messages to him, which correspond with findings on amakwaya wedding songs (Joseph 1983, 75). Similar to amakwaya wedding songs being practised weeks before the wedding (Detterbeck 2002, 212), jangwa wedding songs were frequently sung by young adults for recreation, becoming part of initiation into adulthood and the responsibilities that it entails long before they got married. Therefore, jangwa music serves a rational and educational purpose; sharing knowledge and principles regarding the different roles of people within a society (Harrel, Barret and Petsch 2006, 112).

\section{CONCLUSION}

One of the key aspects of the Manyika culture is marriage and the wedding ceremony that accompanies it, which are exemplified through jangwa wedding songs. Firstly, jangwa songs initiate and welcome the bride into married life; and secondly, the songs remind women as a whole of their pivotal role they play within homes and families. The songs for the bride confirm the distinctive Manyika saying, musha mukadzi (the woman is the pillar of the home). Additionally, the importance which jangwa songs place on the husband as the provider for the family is highlighted. The investigation demonstrates that jangwa music reflects acceptance of both the Western culture of white weddings as well as the continuation of Manyika cultural values and, as such, embodies forms of acculturation (Mans 2005, 7). Since active participation in cultural musical arts experiences is diminishing (Mans 2005, 19), a concerted effort needs to be made to ensure that jangwa wedding music is revived and documented so that this vibrant indigenous musical art form may survive for future generations.

\section{REFERENCES}

Adedeji, O. 2006. Aesthetics and practices in indigenous choral styles of the Yoruba of Africa. In Centering on African practice in musical arts education. Edited by M. Mans. Cape Town: African Minds, 3-16.

Agawu, K. 2003. Defining and interpreting African music. In Musical arts in Africa: Theory, practice and education. Edited by A. Hebst, M. Nzewi and K. Agawu. Pretoria: Unisa Press, $1-12$.

Babbie, E. and Mouton, J. 2008. The practice of social research. Cape Town: Oxford University Press.

Bebey, F. 1999. African music: A people's art (2nd edition). Chicago: Chicago Review Press.

Blacking, J. 1976. How musical is man? London: Faber and Faber. 
Chinouriri, B. 2012. Learning through musical arts: The interplay between musical arts and child development in Shona indigenous milieu. African Musicology Online 6: 44-63.

Detterbeck, M. 2002. South African choral music (amakwaya): Song, contest and the formation of identity. PhD thesis, University of Natal, Durban.

Dontsa, L. 2007. Intonjane music: A forum of identity formation for Xhosa women. In Music and identity: Transformation and negotiation. Edited by E. Akrofi, M. Smit and S. Thorsén. Stellenbosch: Sun Press, 383-396.

Gilbert, J. 2003. Two worlds: Integration, synthesis or conflict. In Psychological perspectives on cultural identity, African Studies Association of Australasia and the Pacific 2003 Conference Proceedings-Africa On a global stage, http:/www.ssn.flinders.edu.au/global/afsaap/ conferences/2003proceedings/gilbert.

Haecker, A.A. 2012. Post-Apartheid South African choral music: An analysis of integrated musical styles with specific examples by contemporary South African composers. PhD thesis, University of Iowa.

Harrel, J., Barret, C. and Petsch, D. 2006. History of aesthetics. New York: Continuum.

Joseph, R 1983. Zulu women's music. African Music Journal of International Library of African Music 6(3): 53-89.

Knoblauch, H. 2005. Focused ethnography. Forum: Qualitative Social Research, 6(3). Available from: http://nbnresolving.de/urn:nbn:de:0114fqs0503440.

Knoblauch, H. and Schnettler, B. 2012. Videography: Analysing video data as a "focused" ethnographic and hermeneutical exercise. Qualitative Research 12(3): 334-356.

Law, G. 2005. Districts of Zimbabwe. Retrieved from www.statoids.com/yzw.html.

Leedy, P.D. and Ormrod, J.E. 2005. Practical research: Planning and design ( $8^{\text {th }}$ edition). Upper Saddle River, NJ: Merrill Prentice Hall.

Mans, M. 2005. Aesthetics and values as core determinants of musical identity formation. Journal of the Musical Arts in Africa 2(1): 1-22.

Mans, M. 2006. Meanings and messages in musical arts. In Centering on African practice in musical arts education. Edited by M. Mans. Cape Town: African Minds, 31-48.

Mindoti, K.W. 2006. The cultural marriage music of the Abaluhya: Song text as a mode of discourse. In Centering on African practice in musical arts education. Edited by M. Mans. Cape Town: African Minds, 157-166.

Mugovhani, N.G. 2012. Shifting identities in South African indigenous cultural practices: A case study of tshikona and tshingombela of Vhavenda communities in Limpopo. Researchgate. net Available from: https://www.researchgate.net/publication/291757293

Mupotsa, D.S. 2014. White weddings. PhD thesis, University of the Witwatersrand, Johannesburg.

Nieuwenhuis, J. 2016. Qualitative research designs and data gathering techniques. In First steps in research ( $2^{\text {nd }}$ edition). Edited by J.G. Maree. Pretoria: Van Schaik, 71-102.

Nzewi, M. 2003. Acquiring knowledge of the musical arts in traditional society. In Musical arts in Africa: Theory, practice and education. Edited by A. Hebst, M. Nzewi and K. Agawu. Pretoria: Unisa Press, 13-37. 
Nzewi, M. and Nzewi, O. 2007. A contemporary study of musical arts informed by African indigenous knowledge systems volume 4: Illuminations, reflections and exploration. Pretoria: African Minds.

Tracey, A. and Uzoigwe, J. 2003. Ensemble. In Musical arts in Africa: Theory, practice and education. Edited by A. Herbst, M. Nzewi and K. Agawu. Pretoria: Unisa Press, 74-94.

Turino, T. 2000. Nationalists, cosmopolitans and popular music in Zimbabwe. Chicago: University of Chicago.

Utete, M.B. 1979. The road to Zimbabwe: The political economy of settler colonialism, national liberation and foreign intervention. Lanham, MD: University Press of America.

Wanyama, M.N. 2005. Forms and content of African music: A case study of Bukusu circumcision music. DMus thesis, University of Pretoria.

Wanyama, M.N. 2006. The philosophy of art reflected in African music: A comparative analysis of Western and African aesthetics. In Centering on African practice in musical arts education. Edited by M. Mans. Cape Town: African Minds, 17-30. 